\title{
Impacts of tourism on geomorphological processes in the Bucegi Mountains in Romania
}

\author{
Bogdan Mihai, Bucharest, Emmanuel Reynard, Lau- \\ sanne, Gabriela Werren, Lausanne, Ionut Savulescu, \\ Bucharest, Ionut Sandric, Bucharest, Zenaida Chitu, \\ Bucharest
}

\section{Introduction}

Because tourism is an economic and social activity that always develops within a territorial context, the phenomenon of tourism may be studied with geographical methods that allow analysis of complexity and impacts in order to mitigate consequences on the environment (see Lozato-Giotard 2003; Michaud 1983; Stock 2003). Numerous geographical studies have, therefore, analysed the reciprocal relationship existing between tourism and geographical concepts, focussing, for example, on landscape (KRIPPENDORF 1977) or mobility (STOCK \& Duhamel 2005), or on specific spatial contexts, like mountains (DEBARBIEUx 1995).

Geomorphology and tourism also influence one another reciprocally: the geomorphological context may contribute to the tourist attraction of specific places, and tourist development may create strong impacts on the landforms (REYNARD et al. 2003, Fig. 1). This relationship is documented in Fig. 1. The original attraction is anything that would draw the attention of tourists to a site in the first place ( $\mathrm{n}^{\circ} 1$ in Fig. 1$)$. Some particularly spectacular landforms - so-called geomorphosites (PANIZZA 2001) or sites of geoheritage - may also be part of the original tourist site $\left(\mathrm{n}^{\circ} 2\right)$. The derived attraction $\left(n^{\circ} 3\right)$ is composed of a set of infrastructures, goods and services that are offered to the tourists to facilitate their visit. Information panels, guided tours or exhibitions related to the Earth Sciences are examples of the derived attraction based on geoheritage (Pralong \& ReYnARd 2005). Both the original and the derived attraction based on geoheritage form geotourism, that is, a form of tourism that aims specifically at the promotion of the geoheritage of a region (NEWSOME \& Dowling 2006). Tourist exploitation $\left(n^{\circ} 4\right)$ of geoheritage may have a negative impact $\left(n^{\circ} 5\right)$ on the ecosystem, leading to a degradation of the geoheritage value, as well as situations of increased risk $\left(\mathrm{n}^{\circ} 6\right.$ and 7). The latter can be created or accentuated by the tourist use of sites where geohazards are particularly intense (e.g. mountains, deserts).

This paper analyses the development of tourism and the intensity of the impacts of tourism within the
Bucegi Plateau area (Romanian Carpathians). Three main steps were taken: a detailed cartography of tourist infrastructures and geomorphological landforms, a study of changes in the vegetation cover by remote sensing, and an analysis of soil erosion on the whole plateau. A specific case study was carried out in the Babele area (see Fig. 2), where the reciprocal relationship between the geoheritage value of geomorphology and the development of natural hazards related to geomorphological processes is particularly evident.

\section{Study area}

\subsection{Geographical setting}

The Bucegi Mountains (Fig. 2) have been the most popular tourist area of the Romanian Carpathians since the 19th century. They cover about $395 \mathrm{~km}^{2}$ and are situated in Central South-Eastern Romania, within the western part of the Curvature Carpathians (Fig. 2). Omu Peak (2505 $\mathrm{m}$ a.s.l.) is the highest point and the orographic main point of the massif. The Bucegi belongs to a nappe structure included within the Eastern Carpathians (Mutinac 1990), called the BucegiLeaota-Piatra Mare Unit. Limited by deep valley sectors and depressions (Fig. 2), like the Prahova valley to the east, a key feature of the Bucegi Mountains is a large development of a structural relief superposed on a faulted upstanding syncline. Large structural and lithological escarpments with relief index up to $1500 \mathrm{~m}$ feature the eastern, northern and north-western sides of the mountains (Fig. 2).

\subsection{Geomorphology and vegetation cover}

The Northern Bucegi Mountains around the Omu Peak feature ten Pleistocene glacial valleys, with relic simple and short glacial troughs, influenced by the structural features of the upstanding syncline. Glaciers no longer exist but large glacial deposits (mainly covered by soil and vegetation) and active debris flows and talus cones are visible. Similar deposits cover the limits between the mountains and the surrounding regions. This landscape is superposed on a complex of monocline structures, formed by Cretaceous carbonate conglomerates and sandstones with crystalline elements (PATrulius 1969), and with local Jurassic limestone block occurrences (klippe and olistholits surrounded by conglomerates, micro conglomerates and sandstones). The limestones feature karstic processes (mainly exokarst with lapies and dolines and a few caves). 


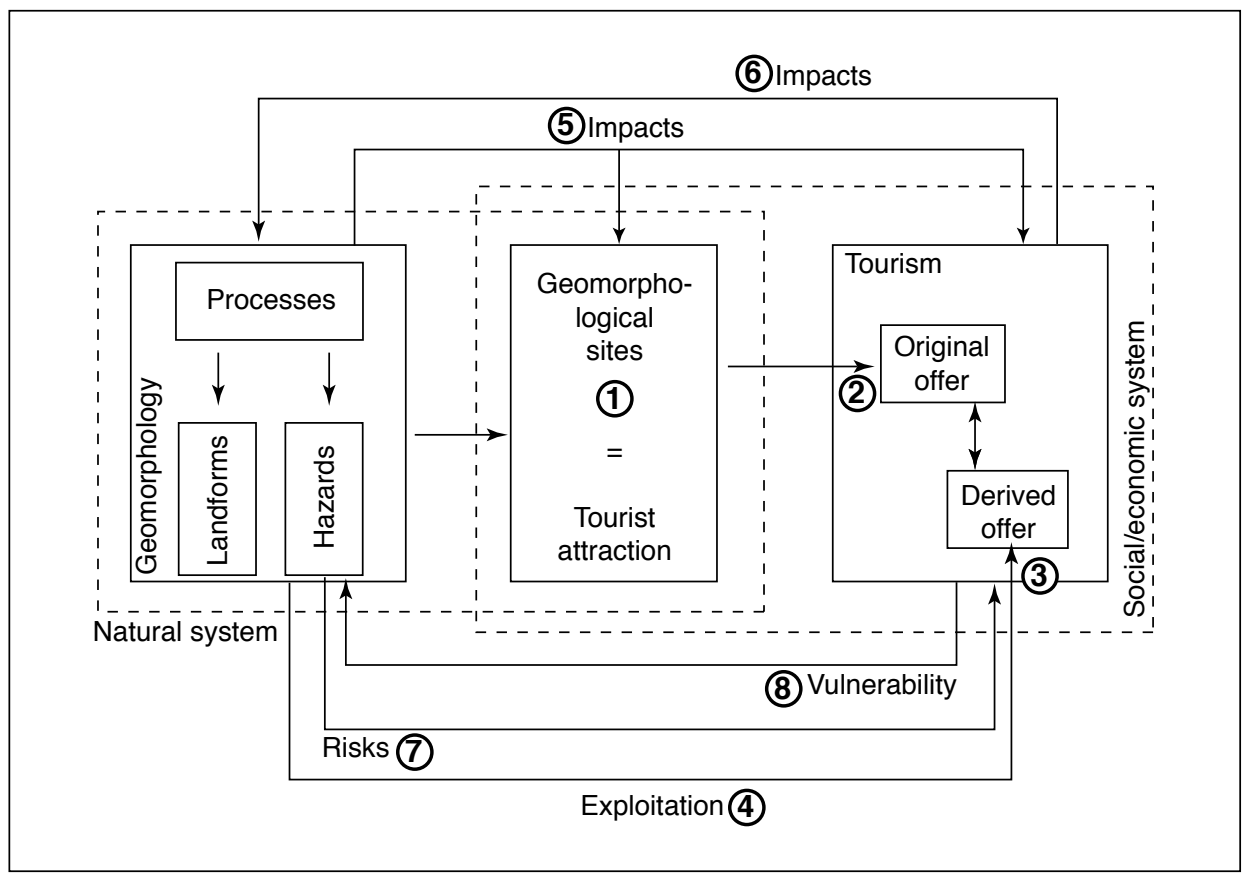

Fig. 1: Relation between geomorphology and tourism Relations existant entre la géomorphologie et le tourisme Beziehungen zwischen Geomorphologie und Tourismus Source: according to Cendrero \& Panizza 1999 and Pralong \& Reynard 2005, modified

The highest area of the Bucegi Mountains is a large complex of structural plateaus at an altitude between 1800 and $2500 \mathrm{~m}$ a.s.l., and a local relief index of no more than 400-500 m (usually 100-200 m). This represents the reverse side, to the west, of the tectonic and erosive cuestas (MicaleVICH-Velcea 1961) with large and impressive steep slopes at more than $45^{\circ}$ to the east, and amplitudes higher than 1000-1500 $\mathrm{m}$ above the Upper Prahova Valley area. This is called the Prahova Valley Escarpment (locally known as abruptul prahovean al Bucegilor) and it is famous for its deep, narrow valleys with waterfalls and systems of cliffs and sharp ridges, as well as near vertical steep slopes, attractive for mountain hikers.

The upstream erosion during the Holocene, from the Prahova Valley to the west (VALSAN 1939), cut the primary watershed and led to the shaping of the main peaks that characterize the area. All of the peaks are structural remnants, small cuestas or hogbacks similar to asymmetrical inselbergs. The axial valley of the plateau is the Izvoru Dorului subsequent stream, which joins the Upper Jepi Valley stream to the north. Both are tributaries to the Prahova River. The plateau is a combination of typical structural surfaces with gradients between $7-15^{\circ}$, cut by temporary streams, with a subsequent role (asymmetric) and consequent or obsequent roles (symmetric), as well as structural remnants separated by saddles of $150-200 \mathrm{~m}$. The landscape is still being shaped, with the Prahova River tributaries expected to capture the Izvoru Dorului stream by sectors (Oprea 2005).

The Bucegi Plateau also preserves a high erosion surface (De Martonne 1981; Micalevich-Velcea 1961; Orghidan 1969; Posea 1998; Valsan 1939) with an uncertain age (Danian-Oligocene or Upper MioceneSarmatian). Here, an interesting micro-landform typology has developed on conglomerates and sandstones (e.g. mushrooms called «babe», sphinxes, columns) as a result of cryonivation and aeolian processes (VELCEA 1987).

Two natural vegetation zones are featured in this landscape, the subalpine zone and the alpine zone, theoretically separated by the $2200-2300 \mathrm{~m}$ contour lines 


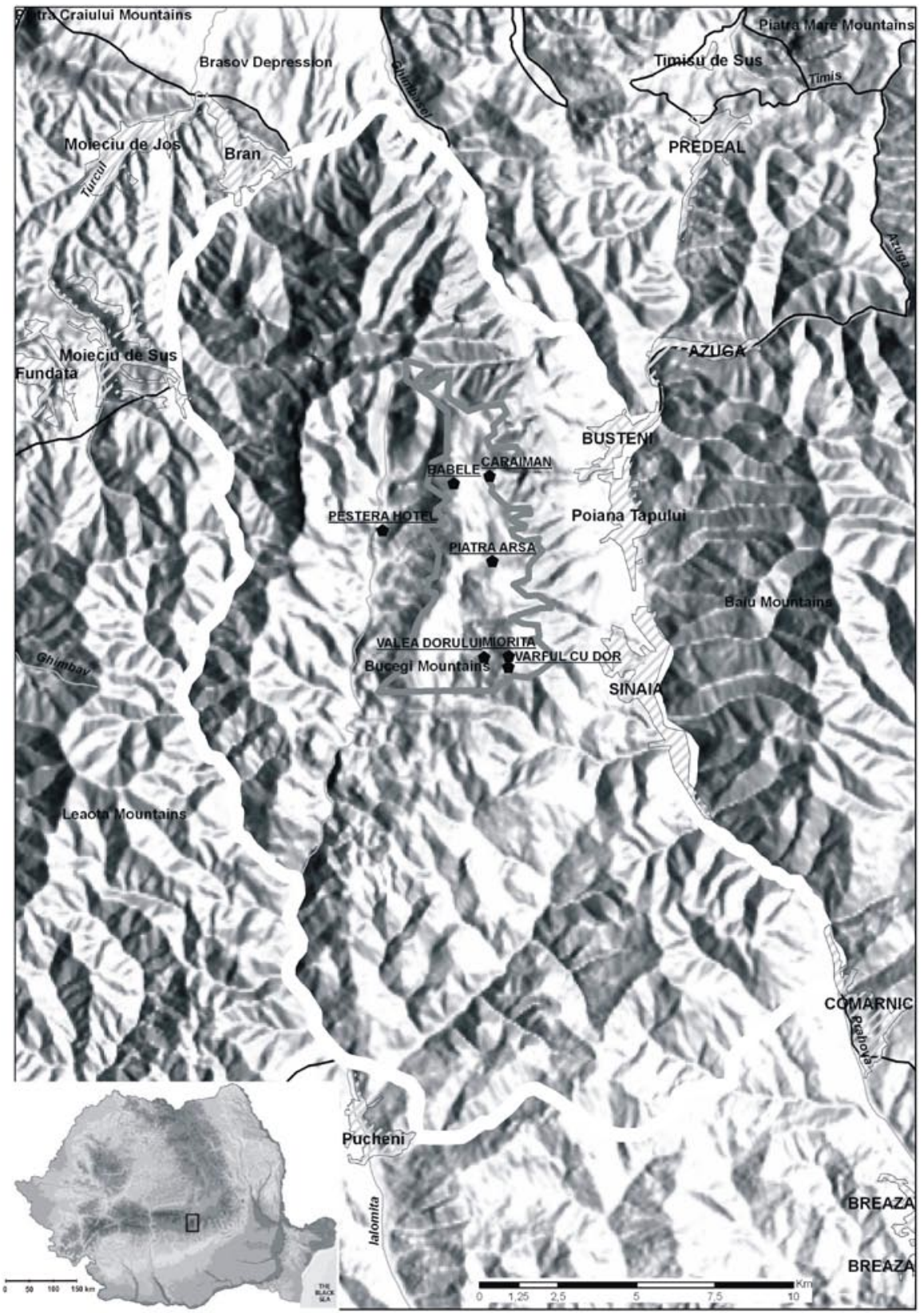

Fig. 2: Location of Bucegi Mountains in Romania in the Western Curvature Carpathians. Schematic map based on a hill-shaded model derived from SRTM elevation data. Grey line marks the research area.

Situation géographique des Monts Bucegi en Roumanie et dans la partie occidentale de la Courbure des Carpates. Carte schématique basée sur un modèle de terrain dérivé de données altitudinales du SRTM. La ligne grise délimite la zone d'étude.

Die geographische Lage der Bucegi Berge in Rumänien und im westlichen Karpatenbogen. Die schematische Karte ist abgeleitet von SRTM Höhendaten. Die graue Linie kennzeichnet das Untersuchungsgebiet.

Source: Global LAND Cover Facility Database 
(BELDIE 1967). All of the Izvoru Dorului catchment, extending over $2 / 3$ of the plateau, is situated within the subalpine area where natural vegetation was a mixture between dwarf pine (Pinus mugo) patches (forests), bushes (e.g. Rhododendron, Vaccinium) and meadows (Puscaru 1956). Higher altitudes are characterized by alpine meadows, where vegetation is poor (small herbs like e.g. Festuca, Agrostis, Poa, lichens from the Cetraria, Cladonia and other genres, small willows like e.g. Salix herbacea, Salix reticulata).

\subsection{Development, tourism and human impacts}

The human impact within the area has made the boundary between these two vegetation zones difficult to assess and map. The Bucegi and the neighbouring mountains have been sheep grazing areas since the 16th century. As a consequence, there are a large number of shepherd huts above the timberline (Popp 1929; Velcea \& Velcea 1965). From the end of the 19th century, settlement along the Prahova Valley increased with establishment of settlements, inns and building of hamlets. The oldest documented settlement is the Sinaia Monastery of 1695 (VelceA et al. 1987).

The area attracted development interest after the building of a modern transcarpathian road in 1847 and a railway between Ploiesti and Predeal in 1879 . In 1881, the Royal Family of Romania built its summer residence at Peles in Sinaia, attracting further tourism and industry to the area. After the first mountain chalet was built in 1888 on Omu Peak, the highest point of Bucegi Mountains, tourism in Bucegi expanded exponentially. Many of the chalets were built during the 1930s. Mass tourism characterised the 1950s, with tourists from Bucharest and other parts of Romania coming to the area to hike. In the 1970s, the number of hikers increased with the building of aerial cable carways from the towns of Sinaia and Busteni in the Prahova Valley. A road was also built during the 1960s from Sinaia to Costila Peak (2498 $\mathrm{m}$ a.s.l.), where a television and radio mast were also erected. The natural subalpine vegetation was increasingly replaced by roads, paths, ski slopes (around Furnica Peak and Valea Dorului) and hotels. Soil erosion intensified after the 1960s and the process still continues.

In 1935, a natural park was created in the Bucegi Mountains. It encompassed mainly the outer steep slopes and some scientific reserves. After ordinance 5/2000 was passed, the Bucegi Natural Park was founded, along with another 15 national and natural parks (ABRUDAN 2009). The park covers a surface of more than 32,600 hectares and extends over three counties (Prahova, Dambovita and Arges). By law, nature conservation and tourism must find a way to coexist within this park.

\section{Methods}

The intensity of tourist development and the impact of these activities on the geomorphic and environmental features of the Bucegi Plateau were studied by using remote sensing, pedological analysis, geomorphological analysis of satellite images, and on-site field survey.

\subsection{Remote sensing}

For the remote sensing-based analysis, use was made of multitemporal imagery comparative analysis. Two images from SPOT satellite were integrated according to their properties. They cover two moments (July 1997 and July 2002). The images are SPOT panchromatic and PanSharpened products.

The first image was a SPOT 4 HRV (High Resolution Visible, panchromatic) satellite subscene from July 1997 at a spatial resolution of $10 \mathrm{~m}$, resized to the limits of the study area, and centred on the area considered to have the highest erosion, the Babele area. The image sharpening process (JENSEN 2005; LILLESAND et al. 2004) needed the prior simulation of the blue spectral channel, based on the other two spectral channels in the visible spectrum, in order to generate a natural colour high-resolution combination.

The second image was a SPOT 5 satellite subscene from July 20, 2002, five years later than the previous image. It had a higher spatial resolution of $5 \mathrm{~m}$. The cloud coverage of both scenes was poor (lower than $2 \%$ ), which allowed a more effective visual analysis.

The different resolutions of the two images did not allow a real change detection procedure. Use had to be made of visual interpretation of erosion-related landforms (rills, gullies, streams and solifluction bodies). Landforms and man-made features were checked onsite during field trips in the summers of 2005 and 2006 using a Global Positioning System (GPS) receiver.

\subsection{Pedological analyses}

The pedological analysis focussed on those podsols in the area most affected by erosion, i.e. around the Babele chalet and cable car upper station. Soil samples were taken at critical points where soil morphological features varied. These points were registered using a GPS receiver and mapped in digital format. Data was collected on soil horizons in quasi natural (less affected) areas with dwarf pine, in subalpine meadow patches, like in the Piatra Arsa area, and in more affected areas where the upper horizons were removed (A and E horizons) or covered by solifluction diluvia (mainly sands with rock fragments). In June 2006, a podsol profile («monolith») not affected by erosion was found in the Piatra Arsa area. This was 
used as a reference sample for comparing the other profiles described within the Babele area. A pedological sounding was possible with simple sounding because the soil thickness was less than 1-1.5 m.

\subsection{Geomorphological and tourist infrastructure mapping}

For the geomorphological analysis, all landforms on the Bucegi Plateau were mapped in detail (Werren 2007). Use was made of the method developed by the Institute of Geography of the University of Lausanne, Switzerland (Schoeneich 1993; Schoeneich et al. 1998). The data collected during the field trip of 2006 was integrated into digitized topographic maps at a scale of 1:25,000. This led to the generation of a detailed geomorphic map at a scale of about 1:20,000 (WERREN 2007). An overlay was created with the information concerning the infrastructure on the Bucegi Plateau. This data was also confirmed by fieldwork, and included e.g. all cable car developments, chalets, hotels, mountain huts, as well as roads and footpaths, pipelines. Other information collected included accommodation capacity of tourist infrastructure to allow assumptions on tourist traffic. Results were verified by means of qualitative data collected during the height of the summer season 2006.

\section{Results}

\subsection{Evolution of tourist infrastructures}

The maps presented in Figure 3 are the result of digitizing cartographic information from several historical maps, tourist guides and tourist maps, as well as data collected during field research. Fig. 3a shows the situation of the plateau before 1914. Some tourist settlements already existed (Hotel Piatra Arsa), a funicular brought visitors to the plateau, the hiking trail network in the southern part was still non-existent, and not yet well developed in the northern part of the plateau. The tourism industry profited from growing industrialisation in the Prahova Valley and the decision of the Royal Family to locate their summer residence in Sinaia. The opening of the Schiel paper factory in the town of Busteni at the end of the 19th century led to the construction of the wood-carrying funicular that crossed the central part of the structural plateau between Piatra Arsa and Nucet. The first tourist associations in Romania were founded in this area. Their programme included the construction of refuge huts and the signposting of hiking trails.

Figure $3 \mathrm{~b}$ depicts the status of tourism on the plateau around 1947. At the end of the First World War, the modern Romanian state emerged. Consequently, the various tourist associations joined forces under the flag of the Romanian Touring Club (TCR). The new organisation developed and signposted most of the present walking trails on the Bucegi upper plateau and built the majority of the mountain huts.

During the Communist regime after Second World War, the role of tourism took a radical change. Tourism was no longer viewed as an elitist activity but was promoted for the good of the proletarian masses. The Prahova Valley and the adjacent eastern part of the Bucegi underwent an intensive development of tourist infrastructures meant to serve mainly the capital's working class. The valley was selected for its accessibility and for the long tourist tradition of the area. The chalets were enlarged, cable cars erected and ski areas created (Fig. 3c). A road network was developed and buildings installed with electricity, gas heating, water and telecommunication facilities. The network of trails between Hotel Piatra Arsa and Babele was enlarged. In addition to the tourist infrastructures, other installations were added: a television antenna on Costila and meteorological stations at Furnica, Babele and Omu (Fig. 3c). The uneven concentration of human activities and infrastructures on the upper plateaus of the Bucegi Mountains is, therefore, a heritage of the Communist era.

Field and data analyses led to the creation of a general map of geomorphological hazards and human impacts on landforms on the plateau (Fig. 4). The map shows that most impacts are related to hiking trails and tourist infrastructures.

\subsection{Vegetation cover and erosion}

Research by MiHai et al. (2006) indicates a general trend of vegetation zone migration to higher altitudes during the 1989/90-2000 period. Beech tree (Fagus silvatica) forests in the Prahova and Ialomita valleys show more stability than mixed forests of beech, spruce fir and fir trees (Abies alba), with significant decrease in the number of spruce fir trees (Picea abies). An average replacement rate of 3-4 $\mathrm{km}^{2}$ per year over a decade was calculated. The study also offers evidence of timberline altitude migration, and draws attention to the competition between the dwarf pine/spruce fir vegetation and pastures/barren land. During the tenyear research period, the coniferous vegetation (dwarf pines, spruce fir trees and fir trees) on the Bucegi Plateau was replaced by pastures $\left(1.9 \mathrm{~km}^{2}\right)$ and non-vegetated land $\left(2.3 \mathrm{~km}^{2}\right)$. In particular, compact zones in the northern part of the region around Babele and in the area between Babele and the Furnica cable way were affected.

These results correlate with an evaluation made by OPREA (2005) on the basis of forestry data and historical documents (old topographic maps and archive photographs from the Romanian Academy Library 

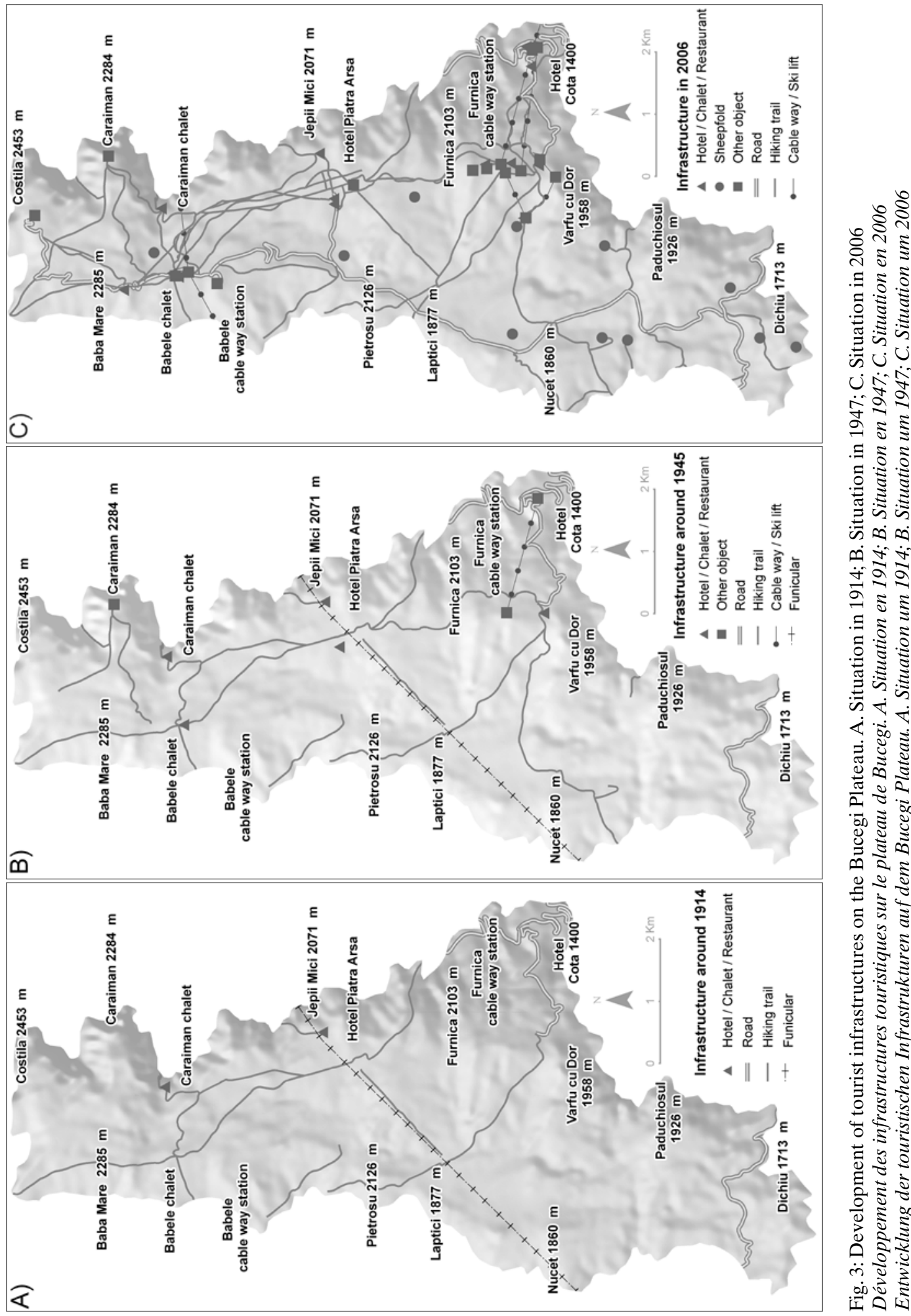

U⿳亠丷⿵冂丶

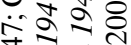
จิ

$\Xi \tilde{5} \tilde{0}$ 등 웡

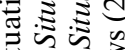
敬品 $\ddot{\dot{x}} \dot{x}$ 종 의 ฐ 1 ธิ : 的部 काष 苟芯芯 त 준 0 का छ : क 2 $\approx \div \frac{0}{ \pm}$ ๑ ये ป ฐ 氝㺼

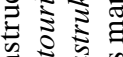
ॠ 5

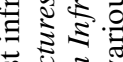
䒺要 ํํำ $=5$

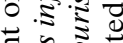
氙 ํㅗㅀ ป 용 ปे

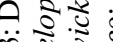
का है है 


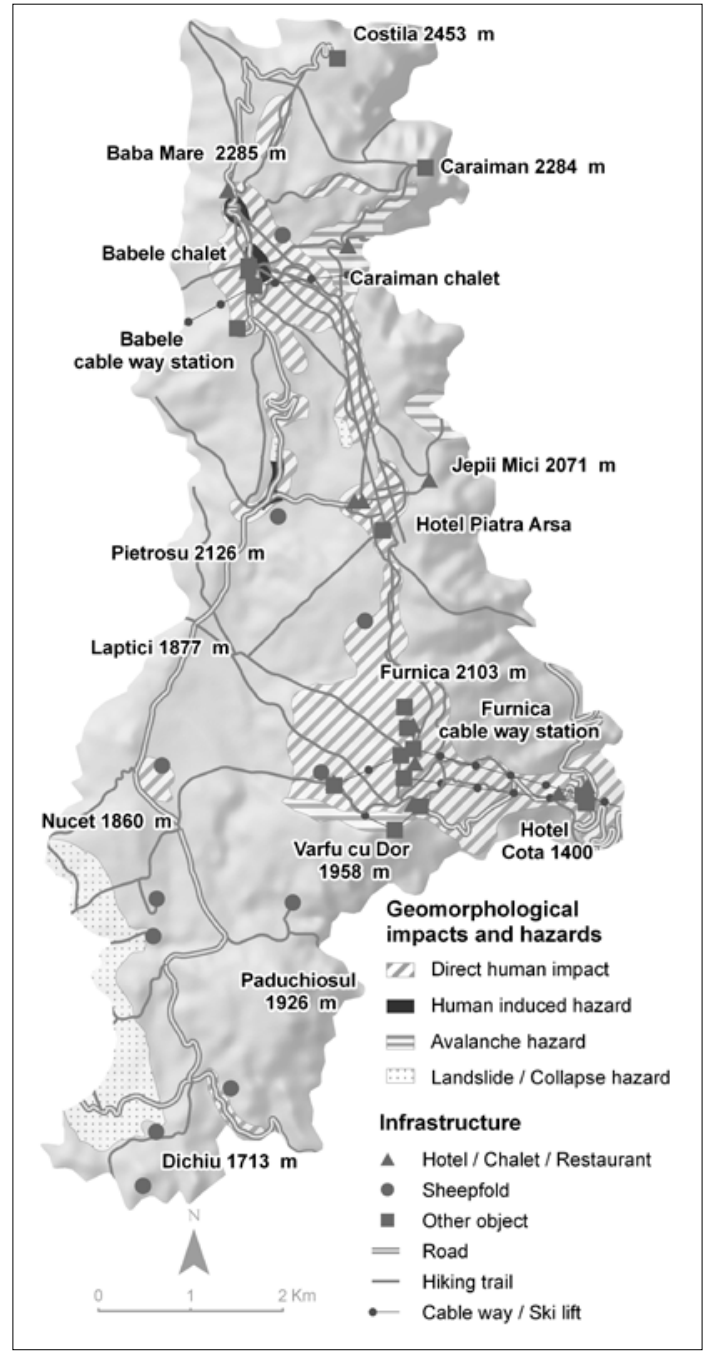

Fig 4: Map of soil erosion intensity on the Bucegi Plateau in the Babele-Patra Arsa area

Carte de l'intensité de l'érosion des sols sur le plateau de Bucegi dans le secteur de Babele-Piatra Arsa

Karte der Bodenerosionsintensität auf dem Bucegi Plateau im Gebiet von Babele-Piatra Arsa

Source: based on a soil mapping campaign (June 2006) coupled with a remote sensing-based analysis

Collections). Here, a continuous regressive trend of the natural vegetation on the Bucegi Plateau could be established. Other results for the Iezer Mountains (Southern Carpathians) show a similar trend for mountain vegetation zones (MiHAI et al. 2007).
For the research project presented here, a remote sensing-based analysis covering a 5-year interval (1997-2002) was coupled with pedological sampling in the field. Attention was paid in particular to podsol, as it is the main soil type in the area affected by erosion (SPIRESCu 1969). Podsol can be seen as an indicator of human impact intensity. With the removal of natural vegetation (mainly dwarf pine associations) over large areas, soil erosion increased (Popova-Cucu 1975). Satellite image analysis was used to map the areas with exposed soil horizons. Natural colour imagery was easy to interpret using soil profile descriptions from the Bucegi Plateau. Where soils were covered by solifluction bodies (like in the Babele area), verification on-site was needed. However, thematic classification was not possible. Further, topographic effects were not eliminated because the Digital Elevation Model (DEM) data available (Shuttle Radar Topography Mission (SRTM) at $90 \mathrm{~m}$ resolution) had errors. The resolution differences did not allow generation of change detection statistics, as done in previous studies in the region (Minai et al. 2006, 2007). Nevertheless, it was possible to draw a qualitative map of the intensity of soil erosion (Fig. 5) using the spectral signatures from the satellite imagery. The map shows that soil erosion is found, in particular, along the network of hiking trails and near certain tourist infrastructures (Babele, Piatra Arsa Hotel, Furnica cable way station). Here, erosion is high with gullies several decimetres deep on steep slopes where regressive erosion is particularly active (Fig. 6 and 7). It is accentuated due to hikers not keeping to the trails. Routes are not protected by stone pavements and the hikers also use the rills and gullies parallel to these roads and paths. This creates large areas of degradation in several sectors (Fig. 6).

There is also a strong link between soil erosion intensity and tourist traffic on the Bucegi Plateau. No statistics were available for tourist numbers in the area, but data collected during the summer holiday period (with two peaks in July and August) gives an idea of the number of tourists visiting the region. As the Bucegi Plateau has a well developed infrastructure, it is assumed that occupation level during the summer season is higher than $80 \%$. On week-ends full capacity is assumed because a significant number of tourists camp overnight near the chalets (Babele, Piatra Arsa, Caraiman). During the last decade, the traffic of the $4 \times 4$ vehicles from the Sinaia mountain resort to Babele along the alpine road increased.

The summer holiday period is also the period with highest average rainfall values. Weather data at $\mathrm{Omu}$ Peak weather station ( $2505 \mathrm{~m}$ a.s.l.) indicates that $65.4 \%$ of total average rainfall occurs during the summer season. The maximum rainfall within 24 hour intervals falls in the months of June $(105.6 \mathrm{~mm})$ and 


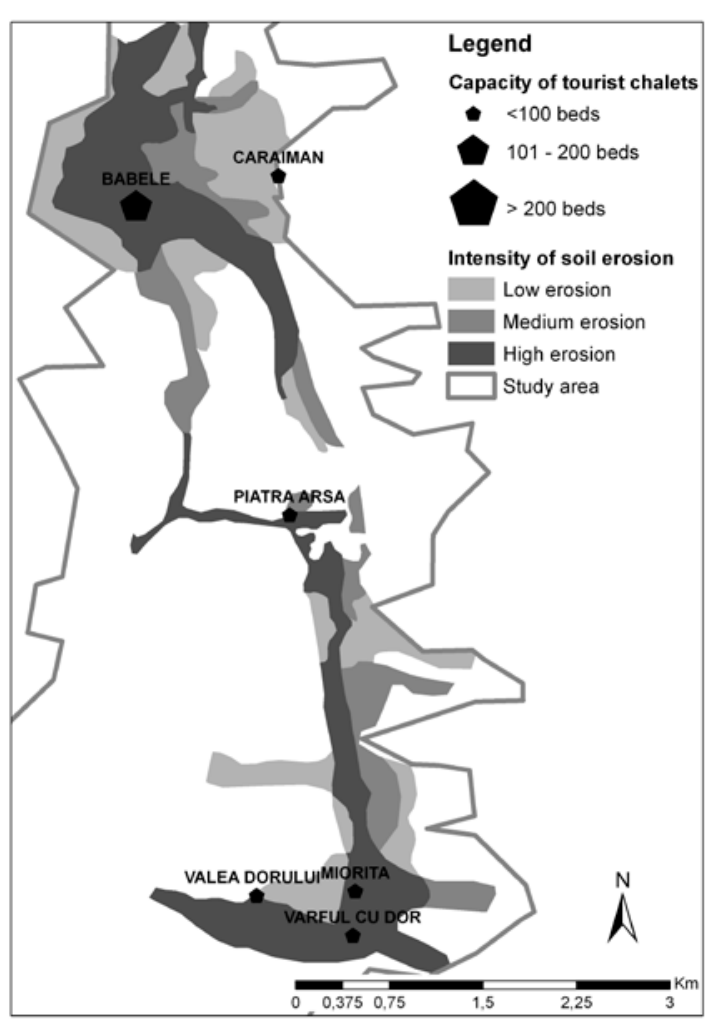

Fig. 5: Relation between tourist chalet capacity and soil erosion intensity on the Bucegi Plateau

Relations existant entre la capacité des infrastructures d'hébergement touristique et l'intensité de l'érosion des sols sur le plateau de Bucegi

Die Kapazität der Touristen-Chalets und die Bodenerosionsintensität auf dem Bucegi Plateau

Source: based on field survey (2006-2007) and remote sensing-based analysis

July $(107.8 \mathrm{~mm})$. An average of 10 thunderstorms is recorded for July.

A correlation map between soil erosion intensity and tourist traffic (Fig. 5) was obtained by overlaying the erosion intensity map with tourist capacity of each chalet in 2008. The largest chalets, such as Babele and Piatra Arsa, are the most accessible, and have the highest level of comfort. These appear to be the nuclei for the spatial expansion of soil erosion on the Bucegi Plateau. These zones are to be found along the main hiking trails which fragment an area covered by subalpine meadows and dwarf pines. It is expected that if current erosion rates continue, this will lead to the development of a large badlands area on the plateau within a few decades.

Previous studies of the Bucegi and Iezer Mountains (Minal et al. 2006, 2007), as well as of the Piatra MarePostavaru Mountains (MinAi 2005) show a general trend of vegetal recovery on lands affected by surface and gully erosion due to anthropic rehabilitation. On the degraded podsols of the subalpine and alpine zones of the Bucegi Plateau, meadow vegetal recovery is a difficult process. The reason is related to the soil features, in particular to soil texture (granulometric classes) and pH levels (Fig. 8). The organic horizon of the podsol (topsoil, A) has a medium to coarse texture and a low to medium acid reaction, which is favourable for root system development. If the topsoil layer is removed, the coarse texture and very acidic reaction of the $\mathrm{E}$ (eluvial) and $\mathrm{B}$ (illuvial) horizons ( $\mathrm{pH}$ is lower than 4.0 in the $\mathrm{E}$ horizon) limit the development of vegetation root systems. These soil features are a limiting factor for short-term vegetal recovery and ecosystem equilibrium on the Bucegi Plateau.

Heavy rainfall during the summer season (that corresponds to tourist traffic peak along trails) can also hinder the natural process of soil and vegetal recovery. Thus, the subalpine and alpine ecosystems on the Bucegi Plateau may be considered particularly vulnerable.

\subsection{The Babele area}

The analysis also focussed on the area around Babele chalet $(2206 \mathrm{~m})$ for several reasons:

- For many centuries, the area was covered by dwarf pines, which have since been almost completely removed, initially for grazing purposes and then for the development of tourist paths, roads and buildings;

- since the end of the 1930s, Babele chalet is a hub of tourist activity in the central area of the Bucegi Plateau;

- since the opening of the cable car in 1978, this area has seen a steady increase in tourist numbers during summer, when the season peak coincides with a period of high-intensity rainfall;

- the Babele area is a representative geomorphosite in the Romanian Carpathians with unusual natural landforms, e.g. the «Babele» (mushroom-shaped landforms in Cretaceous microconglomerates and sandstones) (Fig. 9) and the «Sphynx» (a shape of a head of a man with a cap, formed in the same rocks).

The results of geomorphological mapping carried out in this area are presented in Fig. 10. All around the Babele chalet, deep gullies are visible (see also Fig. 9). The removed material accumulates on alluvial fans in the depressions (Fig. 10). Geomorphological degradation is coupled with bad management of the rubbish 

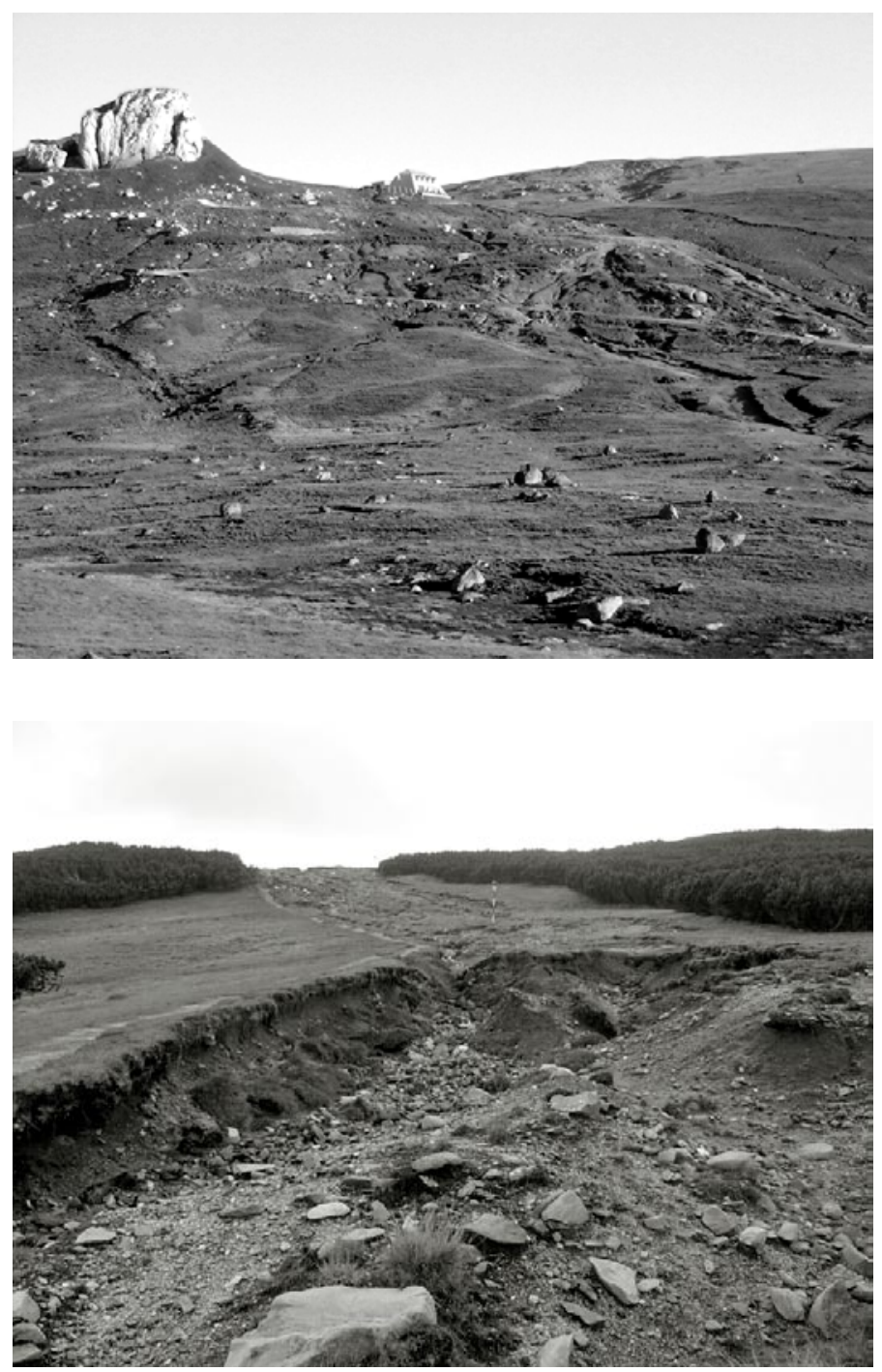

Fig. 6: Erosion gullies near Babele chalet

Rigoles d'érosion à proximité du refuge de Babele

Erosionsrinnen in der Nähe des Babele Chalets

Photo: I. SAVULESCU

Fig. 7: Erosion gully along hiking paths in the Piatra Arsa area. Erosion is accentuated by the absence of a well signposted path.

Rigole d'érosion le long de sentiers de randonnée dans le secteur de Piatra Arsa. L'érosion est favorisée par l'absence d'un chemin clairement défini.

Erosionsrinne entlang der Wanderwege im Gebiet Piatra Arsa. Die Erosion wird begünstigt durch das Fehlen von klar definierten Wegen. Photo: I. SAVULESCU

produced by tourists (Werren 2007). Weathering landforms considered geomorphosites are protected by low fences, but numerous examples of anthropogenic degradation are visible and these landforms are surrounded by a dense footpath network and eroded surfaces (Fig. 9 and 11).

\section{Conclusions and perspectives}

The Bucegi Mountains, and especially their plateau landscape, have probably been affected by anthropogenically induced processes since the 16th century. Tourist related activities have increased especially since the first half of the 20th century. Clearing of dwarf pines for agricultural, then infrastructural purposes, has been a major issue. Although the Romanian Government passed the first environmental conservation measures for the Bucegi Mountains in 1943, these did not put an end to dwarf pine clearing.

After the 1950s, Bucegi was faced with mass tourism. Tourist impact was further intensified with the inauguration of a cable way in the 1960s-1970s. Natural vegetation was progressively replaced by pastures (usually overgrazed). Soils eroded, barren areas and rock outcrops became frequent. The road and path network is currently about $95 \mathrm{~km}$ long and has an 


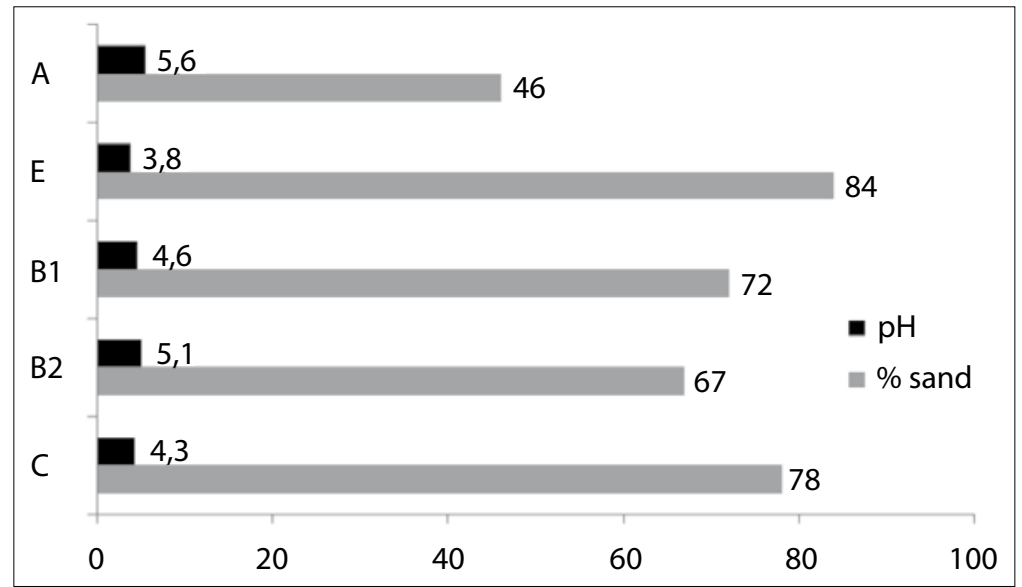

Fig. 8: Soil texture (\% sand) and reaction $(\mathrm{pH})$ for a podsol sample from the Bucegi Plateau, Babele chalet Texture du sol (\% de sable) et réaction ( $p H$ ) pour un échantillon de podzol du plateau de Bucegi, secteur du refuge de Babele

Bodentextur (\% Sand) und Reaktion ( $p H$ ) einer Podsol-Probe des Bucegi Plateaus im Gebiet des Babele Chalets Data source: ReseArch Institute For SoIL AND Agrochemistry (ICPA), Bucharest; graphics: I. SAVulescu

average density of $4.8 \mathrm{~km} / \mathrm{km}^{2}$ (OPREA 2005); $52 \mathrm{~km}$ are marked as tourist paths. This is a key factor for the regressive evolution of the vegetal cover. Since the 1990s, experiments have been carried out to save the existing vegetation and to stop the aggressive erosion process. Small terraces on the contour line and different drainage devices were tried out on experimental plots, for example near Babele cable way station.

In order to promote a sustainable development of tourism on the plateau, it is argued here that three main courses of action should be taken. The first one is a redrawing of the whole road and footpath network. Some paths should be closed and hiking should be concentrated on a smaller network of well signposted paths reinforced against erosion. The second suggestion is to restore the vegetal cover on degraded slopes by construction of micro terraces. Experiments related to this line of action show good results for the area around Babele chalet, but the costs are very high. Finally, interest in the geomorphological landforms of the area (Babele geomorphosites) and education of tourists about the effects of erosion should be promoted. Knowledge of the processes of erosion caused by tourists should make them more sensitive to the effects of their own impact on the environment. It is suggested that these actions could be integrated into a directory plan to be implemented, for example, by the nature park administration.

\section{References}

Abrudan, I. (coord.) (2009): Parcul Natural Bucegi. - http://www.bucegipark.ro 28.02.2009.

BeldIE, A. (1967): Flora si vegetatia Muntilor Bucegi. - Bucuresti: Editura Academiei.

Cendrero, A. \& M. Panizza (1999): Geomorphology and environmental impact assessment: an introduction. - In: Suppl. Geografia Fisica e Dinamica Quaternaria III/3: 167-172.

De Martonne, E. (1981): Cercetari asupra evolutiei geomorfologice a Alpilor Transilvaniei. - Bucuresti: Editura Academiei.

Debarbieux, B. (1995): Tourisme et montagne. - Paris: Economica.

JENSEN, J. (2005): Introductory digital image processing. - New Jersey: Prentice Hall.

KRIPPENDORF, J. (1977): Les dévoreurs de paysages. Le tourisme doit-il détruire les sites qui le font vivre? - Lausanne: Editions 24 heures.

Lillesand, T., Kiefer, R. \& J. Chipman (2004): Remote sensing and image interpretation. - New York: Wiley.

LozATo-Giotard, J.-P. (2003): Géographie du tourisme. De l'espace consommé à l'espace maîtrisé. - Paris: Pearson.

Micalevich-Velcea, V. (1961): Masivul Bucegi. Studiu geomorfologic. - Bucuresti: Editura Academiei.

Michaud, J.-L. (1983): Le tourisme face à l'environnement. - Paris: Presses Universitaires de France PUF.

MinaI, B. (2005): Muntii Timisului (Carpatii Curburii). Potential geomorfologic si amenjarea spatiului 


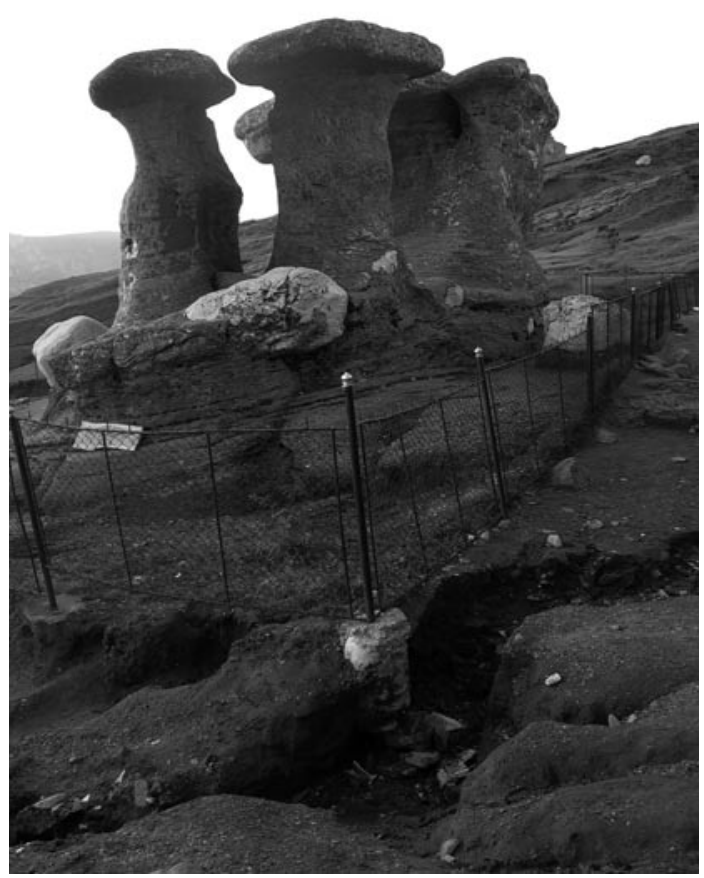

Fig. 9: The Babele, a mushroom-shaped landform recognised as a natural monument by the Romanian Government. Note the intense soil erosion around the site.

Le Babele, une forme d'érosion (champignon) reconnue comme monument naturel par le gouvernement roumain. A noter l'intense érosion des sols autour du site.

Babele, eine pilzförmige Erosionsform, von der rumänischen Regierung als Naturdenkmal anerkannt. $\mathrm{Zu}$ beachten ist die starke Bodenerosion an dieser Stelle. Photo: E. REYNARD

montan. - Bucuresti: Editura Universitatii din Bucuresti.

Mihai, B., Savulescu, I., SAndric, I. \& R. Oprea (2006): Apports de la méthode de détection des changements pour l'évaluation de la dynamique de l'étagement de la végétation dans les Monts de Bucegi (Carpates Méridionales, Roumanie). - In:Télédétection 6, 3:215231.

Mihai, B., Savulescu, I. \& I. Sandric (2007): Change detection analysis (1986/2002) for the alpine, subalpine and forest landscape in Iezer Mountains (Southern Carpathians, Romania). - In: Mountain Research and Development 27, 3: 250-258.
Mutihac, V. (1990): Structura geologica a teritoriului Romaniei. - Bucuresti: Editura Tehnica.

Newsome, D. \& R.K. Dowling (2006): The scope and nature of geotourism. - In: Dowling, R.K. \& D. NewSOME (eds): Geotourism: sustainability, impacts and management. - Oxford: Elsevier: 3-25.

OpreA, R. (2005): Bazinul montan al Prahovei. Studiul potentialului natural si al impactului antropic asupra peisajului. - Bucuresti: Editura Universitara.

OrghidAN, N. (1969): Vaile transversale din Romania. - Bucuresti: Editura Academiei.

PAnizzA, M. (2001): Geomorphosites: concepts, methods and example of geomorphological survey. - In: Chinese Science Bulletin 46, Supplement: 4-6.

Patrulius, D. (1969): Geologia Masivului Bucegi si a Culoarului Dambovicioara. - Bucuresti: Editura Academiei.

Popova-Cucu, A. (1975): Rolul jnepenisurilor si al arinisurilor de munte in mentinerea echilibrului natural in Carpati. - In: Ocrotirea naturii si a mediului inconjurator 1, Bucuresti: 47-51.

Popp, N. (1929): Valea Prahovei intre Predeal si Floresti. Observatii antropogeografice. - In: Buletinul Societatii Regale Romane de Geografie 48: 185-258.

Posea, G. (1998): Suprafetele de nivelare din Muntii Piatra Craiului-Baiu (Carpatii de Curbura) - In: Analele Universitatii Spiru Haret, Seria Geografie 1:7-18. Pralong, J.-P. \& E. Reynard (2005): A proposal for a classification of geomorphological sites depending on their tourist value. - In: Il Quaternario 18, 1: 313-319.

Puscaru, D. (coord.) (1956): Pasunile alpine din Muntii Bucegi. - Bucuresti: Editura Academiei.

Reynard, E., Holzmann, C., Guex, D. \& N. SummerMATTER (eds) (2003): Géomorphologie et tourisme. - = Travaux et Recherches 24, Lausanne, Institut de Géographie.

Schoeneich, P. (1993): Comparaison des systèmes de légendes français, allemand et suisse - principes de la légende IGUL. - In: Schoeneich, P. \& E. REYNARD (eds): Cartographie géomorphologique, cartographie des risques. - = Travaux et Recherches 9, Lausanne, Institut de Géographie: 15-24.

Schoeneich, P., Reynard, E. \& G. Pierrehumbert (1998): Geomorphological mapping in the Swiss Alps and Prealps. - In: Wiener Schriften zur Geographie und Kartographie 11: 145-153.

SpIREScu, M. (coord.) (1969): Solurile Muntilor Bucegi. - Bucuresti: Editura Academiei.

Stock, M. (dir.) (2003): Le tourisme. Acteurs, lieux et enjeux. - Paris: Belin.

Stock, M. \& P. Duhamel (2005): A practice-based approach to the conceptualisation of geographical mobility. - In: BELGEO, Revue Belge de Géographie 1-2: 59-68.

VAlsan, G. (1939): Morfologia Vaii superioare a Prahovei si a regiunilor vecine. - In: Buletinul Societatii Regale Romane de Geografie 58:1-44. 


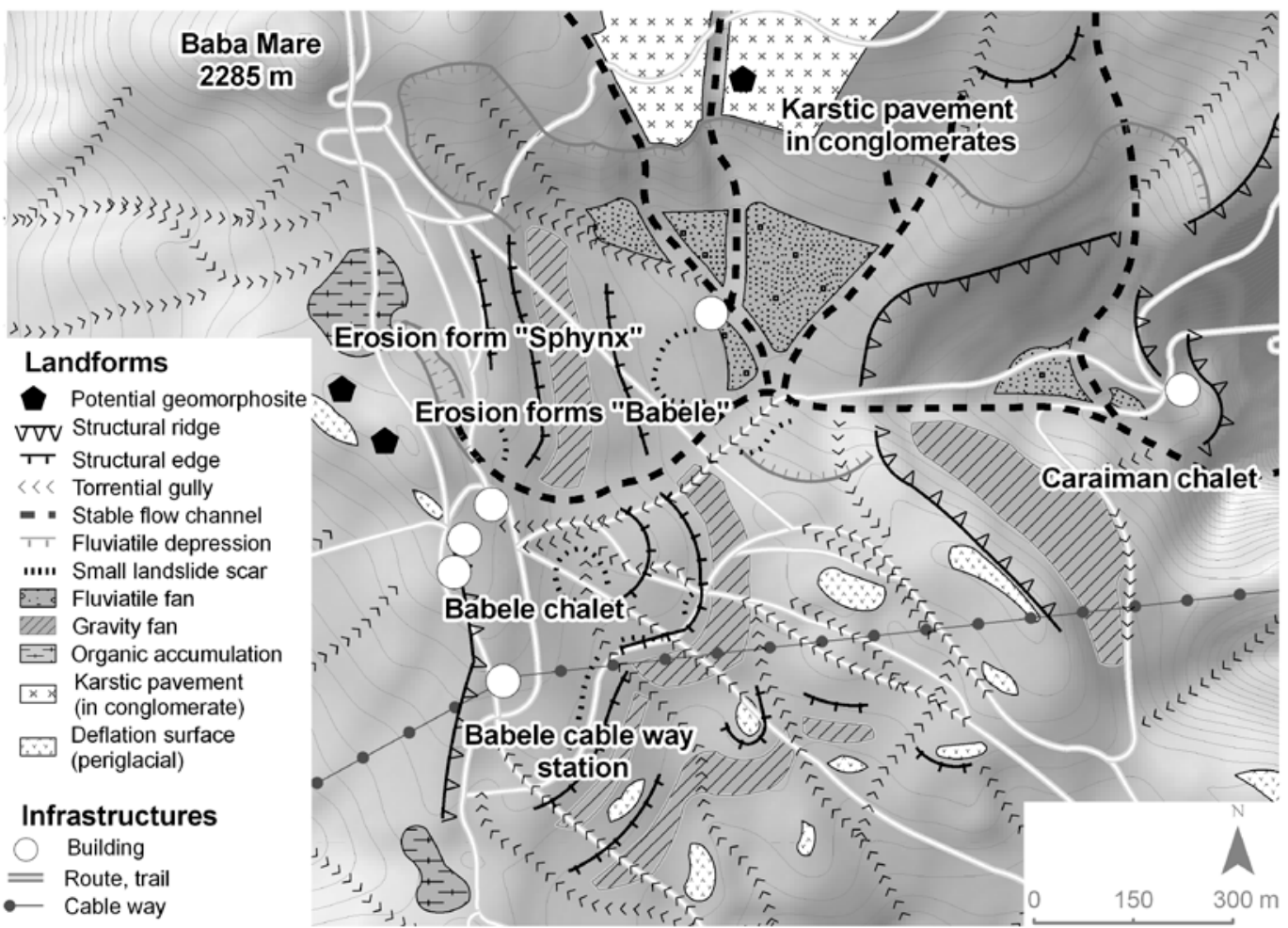

Fig. 10: Section of the geomorphological map of the Bucegi Plateau

Extrait de la carte géomorphologique du plateau de Bucegi

Auszug der geomorphologischen Karte des Bucegi Plateaus

Data source: field survey 2006-2007; cartography: G. WERREN

Velcea, V. (1987): Masivul Bucegi. - In: Geografia Romaniei. Carpatii Romanesti si Depresiunea Transilvaniei 3. - Bucuresti, Editura Academiei: 247-251.

Velcea, V. \& I. Velcea (1965): Valea Prahovei. Bucuresti: Editura Stiintifica.

Velcea, V., Cucu, V. \& I. Velcea (1987): Culoarul Prahovei. - In: Geografia Romaniei. Carpatii Romanesti si Depresiunea Transilvaniei 3. - Bucuresti, Editura Academiei: 260-265.

WerRen, G. (2007): La géomorphologie face aux activités touristiques sur le plateau structural de Bucegi, Roumanie. - Université de Lausanne, Institut de Géographie, unpublished master thesis.

\section{Abstract: Impacts of tourism on geomorphological processes in the Bucegi Mountains in Romania}

The Bucegi Mountains are situated in the Curvature Carpathians close to the metropolitan area of Bucharest. Tourism has been promoted on the Bucegi Plateau since the 1930s with the establishment then of several hotels and chalets. During the communist period after World War II, the area targeted mass tourism with the creation of a large network of hiking paths. Increased heating needs led to the almost complete removal of dwarf pine cover. The current situation is characterised by intense vegetation and soil degradation and by active gullying along the hiking trails and around the main tourist infrastructures. This study proposes a strategy for sustainable tourism development on the plateau based on an analysis of both local tourist infrastructure development during the $20^{\text {th }}$ century and impacts of tourism on vegetation and soil erosion during the last decade. It is argued that erosion can be counterbalanced by redesigning the tourist path network, rehabilitating the degraded slopes and raising the awareness of tourists concerning geomorphological processes.

Keywords: Bucegi (Romania), tourism, erosion, geomorphosites, infrastructures 


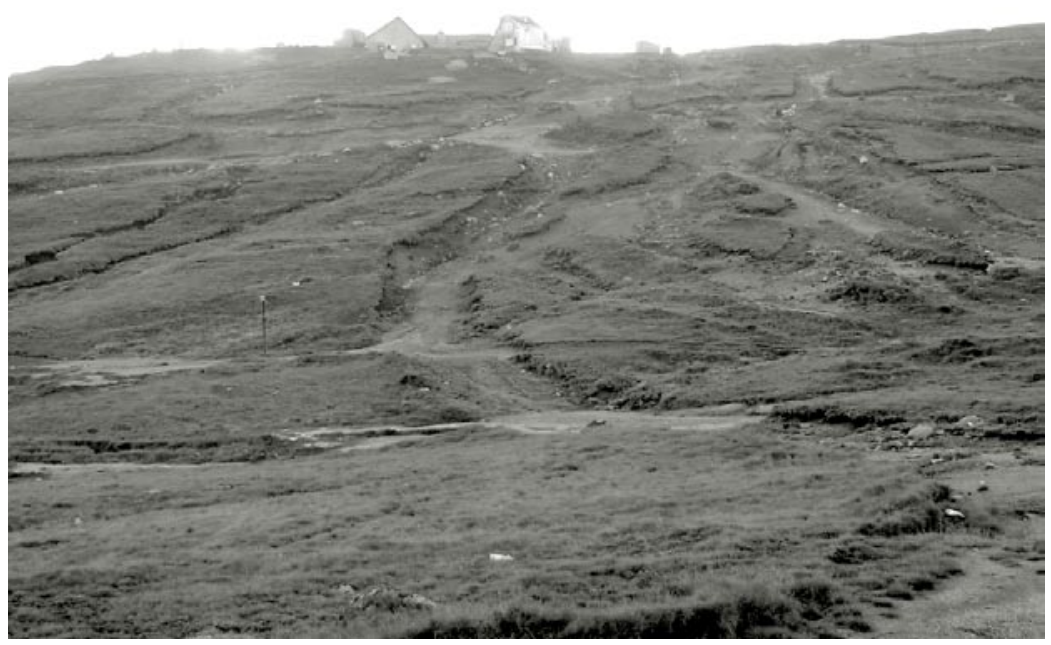

Fig. 11: Soil erosion around Babele chalet. Note the intense erosion along footpaths.

Erosion des sols près du refuge de Babele. A noter l'intense érosion le long des sentiers de randonnée.

Bodenerosion um das Babele Chalet herum. Zu beachten die starke Erosion entlang der Wanderwege.

Photo: I. SAVULESCU

\section{Résumé: Impacts du tourisme sur les processus géo- morphologiques dans les Monts Bucegi (Roumanie)}

Les Monts Bucegi sont situés dans la courbure des Carpates, à proximité de la zone métropolitaine de Bucarest. Le tourisme s'est développé sur le plateau de Bucegi depuis les années 1930, suite à la construction de plusieurs refuges et hôtels. Après la Deuxième Guerre mondiale, le gouvernement communiste a promu le développement d'un tourisme de masse qui s'est traduit par la création d'un important réseau de chemins de randonnée pédestre. La forêt originelle de pins a été presque complètement détruite, principalement pour satisfaire les besoins en bois de chauffage. Cette étude vise à analyser le développement des infrastructures touristiques durant le XXème siècle, à mettre en évidence les impacts récents (dernière décennie) du tourisme sur la végétation et sur l'érosion des sols et à proposer une stratégie de développement touristique durable sur le plateau de Bucegi. Actuellement, on observe une intense dégradation végétale et des sols associée à une importante érosion par ruissellement le long des sentiers et autour des infrastructures touristiques. Une réduction des phénomènes d'érosion nécessiterait d'optimiser le réseau de sentiers, de réhabiliter les zones dégradées et d'informer les touristes sur les processus géomorphologiques.
Mots-clés: Bucegi (Roumanie), tourisme, érosion, géomorphosites, infrastructures

\section{Zusammenfassung: Einwirkungen des Tourismus auf geomorphologische Prozesse in den Bucegi Bergen (Rumänien)}

Die Bucegi Berge liegen nahe der Metropolregion Bukarest im Karpatenbogen. Der Tourismus entwikkelte sich auf dem Bucegi Plateau seit den 1930er Jahren, als verschiedene Chalets und Hotels entstanden. Während der kommunistischen Periode nach dem Zweiten Weltkrieg wurde der Massentourismus gefördert, und es entstand ein grosses Wanderwegenetz. Die Zwergföhrendecke wurde fast vollständig als Brennmaterial abgeholzt. Die vorliegende Studie analysiert die Entwicklung der touristischen Infrastrukuren während des 20. Jahrhunderts, ferner die jüngsten Einflussfaktoren (letztes Jahrzehnt) des Tourismus auf Vegetation und Bodenerosion. Es wird eine Strategie für eine nachhaltige Tourismusentwicklung auf dem Plateau vorgeschlagen. Eine starke Vegetations- und Bodendegradation sowie die Bildung von Rillen entlang der Wanderwege und in der Umgebung touristischer Infrastrukturen kennzeichnen die heutige Situation. Eine Reduktion der Erosion sollte durch Optimieren des Wegenetzes, die Wiederherstel- 
lung der degradierten Hänge sowie Aufklärung von Touristen über geomorphologische Prozesse realisiert werden.

Schlüsselwörter: Bucegi (Rumänien), Tourismus, Erosion, geomorphologische Geotope, Infrastrukturen

Prof. Dr. Bogdan Mihai, Facultatea de Geografie, Universitatea din Bucuresti, Bdul. Nicolae Balcescu nr. 1, Sector 1, 010041 Bucuresti, Romania.

e-mail: bogdan@geo.unibuc.ro

Prof. Dr. Emmanuel Reynard, Institut de géographie, Université de Lausanne, Bâtiment Anthropole, $\mathrm{CH}-$ 1015 Lausanne, Switzerland.

e-mail: Emmanuel.Reynard@unil.ch

Géogr. dipl. Gabriela Werren, Institut de géographie, Université de Lausanne, Bâtiment Anthropole, CH1015 Lausanne, Switzerland.

e-mail: Gabriela.Werren@unil.ch
Lect. Ionut Savulescu, Facultatea de Geografie, Universitatea din Bucuresti, Bdul. Nicolae Balcescu nr. 1, Sector 1, 010041 Bucuresti, Romania.

e-mail: savulescu@geo.unibuc.ro

Lect. Dr. Ionut Sandric, Facultatea de Geografie, Universitatea din Bucuresti, Bdul. Nicolae Balcescu nr. 1, Sector 1, 010041 Bucuresti, Romania.

e-mail: sandricionut@yahoo.com

Dipl. Geogr. Zenaida Chitu, Facultatea de Geografie, Universitatea din Bucuresti, Bdul. Nicolae Balcescu nr. 1, Sector 1, 010041 Bucuresti, Romania.

e-mail: zenaidachitu@yahoo.com

Manuskripteingang/received/manuscrit entré le

13.4.2009

Annahme zum Druck/accepted for publication/accepté pour l'impression: 15.9.2009 